\title{
KONSTYTUCJE INSTYTUTÓW ŻYCIA KONSEKROWANEGO JAKO KODEKS ŻYCIA DUCHOWEGO
}

Konstytucje instytutów życia konsekrowanego, czy to zakonnych, czy świeckich, są najczęściej kojarzone z tekstem jurydycznym, przeznaczonym do konsultowania w określonych sytuacjach, kiedy trzeba dokonać jakichś aktów prawnych. Czy jest to słuszne podejście? Skąd się wzięło? Jak można i należałoby popatrzeć na konstytucje w pełniejszym świetle? Na te pytania pragnie dać odpowiedź autor artykułu, wskazując kierunek tej refleksji już w tytule. Celem niniejszego opracowania jest przybliżyć osobom konsekrowanym ich konstytucje, pomóc im w dostrzeżeniu, że teksty te kryją w sobie treści ważne dla życia duchowego, niekoniecznie dostrzegane przy pobieżnej lekturze.

\section{I. ŻYCIE KONSEKROWANE ŻYCIEM EWANGELICZNYM}

Życie konsekrowane w Kościele jest niczym innym, jak jednym ze sposobów przeżywania życia chrześcijańskiego, a więc życia opartego na Ewangelii. Bardzo wymowne w tym względzie jest doświadczenie monastycyzmu w pierwszych wiekach istnienia naszej wiary. Powszechnie przyjmuje się, że jedną $z$ głównych przyczyn rozprzestrzeniania się monastycyzmu było ustanie prześladowań Kościoła i rozpoczęcie okresu większej wolności działania. Zwłaszcza po edykcie mediolańskim z 313 roku bycie chrześcijaninem nie tylko nie wiązało się już z ryzykiem utraty życia, ale wręcz przeciwnie, oznaczało przynależność do uprzywilejowanej grupy społecznej. To wpłynęło na szybki wzrost liczby ochrzczonych i zarazem na obniżenie poziomu życia religijno-moralnego chrześcijan. Wobec takiego stanu rzeczy niektórzy bardziej wrażliwi uczniowie Jezusa decydowali się na opuszczenie swoich domów i majętności, by udać się na miejsca odosobnione w celu pielęgnowania ducha wyrzeczenia zawartego 
w Ewangelii. Tak powstał monastycyzm, najpierw eremicki, potem wspólnotowy. Wśród ideałów organizujących życie pierwszych mnichów znalazły się wartości ogólnochrześcijańskie: pragnienie naśladowania Chrystusa, życie na wzór pierwszej wspólnoty chrześcijańskiej w Jerozolimie, walka z demonem, oczekiwanie na powtórne przyjście Pana ${ }^{1}$. Jest to widoczne zwłaszcza w monastycyzmie św. Bazylego Wielkiego (329-379), który nazywa swoich mnichów po prostu chrześcijanami, a za podstawowe prawo, jakim winni się kierować, uważa miłość Boga i bliźniego. Wspólnota w jego ujęciu ma być właśnie przestrzenią realizowania tego prawa ${ }^{2}$.

W naszych czasach nie brakuje autorytatywnych wypowiedzi Kościoła, które potwierdzają ewangeliczny charakter życia konsekrowanego. Ograniczę się do zaledwie dwóch cytatów:

Zakonnicy powinni gorliwie starać się o to, aby za ich pośrednictwem Kościół, zarówno wierzącym, jak niewierzącym, stale coraz lepiej rzeczywiście ukazywał Chrystusa - bądź to oddającego się kontemplacji na górze, bądź zwiastującego rzeszom królestwo Boże, bądź uzdrawiającego chorych i ułomnych, a nawracającego grzeszników ku dobru, bądź błogosławiącego dzieci i czyniącego dobrze wszystkim, a jednocześnie zawsze posłusznego woli $\mathrm{Oj}$ ca, który Go posłał (LG 46).

Autentyczne odrodzenie życia zakonnego jest możliwe tylko wtedy, kiedy staramy się prowadzić życie w pełni ewangeliczne, niczego nie przedkładając nad jedyną Miłość, lecz znajdując w Chrystusie i Jego słowie najgłębszą istotę każdego charyzmatu założyciela ${ }^{3}$.

Chciałbym zwrócić uwagę, że w powyższych tekstach Kościół mówi o życiu zakonnym, a szerzej rzecz ujmując, o życiu konsekrowanym ${ }^{4}$, jako ewangelicznym, podkreślając jednocześnie fakt posiadania przez dany instytut życia konsekrowanego własnego charyzmatu. Charyzmat własny jest specyficznym ujęciem przesłania Ewangelii, umiłowaną cząstką czy też bramą, przez którą konsekrowani instytutu wchodzą do życia chrześcijańskiego. Dzięki niemu ich życie chrześcijańskie, czy też ewangeliczne, nie jest ogólnikowe, lecz specyficzne, zgodnie $z$ otrzymanym od Boga darem.

\footnotetext{
Por. A. Favale, Vita consacrata e società di vita apostolica. Profilo storico, Roma 1992, s. 17-18. Por. tamże, s. 26.

Por. Benedykt XVI do osób konsekrowanych, red. M. Saj, Kraków 2009, s. 29.

4 Zacytowany tekst soborowy używa ok reślenia „życie zakonne”, ponieważ nie istniała wówczas inna forma życia konsekrowanego, oprócz rodzących się dopiero instytutów świeckich, stąd też nie odczưwano jeszcze wyraźnie potrzeby zmiany terminologii. Natomiast przemówienie papieskie odnosi się do dekretu soborowego Perfectae caritatis o przystosowanej odnowie życia zakonnego, lecz cytowany fragment ma zasięg szerszy.
} 
Ta uwaga ma dla nas kluczowe znaczenie, gdyż konstytucje w dzisiejszym kształcie mają być kodeksem fundamentalnym (por. KPK 587) dla osób konsekrowanych danego instytutu, projektem życia ewangelicznego ${ }^{5}$. Zawierając sformułowanie charyzmatu własnego danego instytutu, wyrażają przede wszystkim ewangeliczne wartości, które stanowią oś jego życia. W ten też sposób stają się jakby Ewangelią w kluczu instytutu ${ }^{6}$ - „ewangelistą”, kontynuując analogię, jest założyciel. W istocie to on zakreśla, choćby ogólnie i nie na piśmie ${ }^{7}$, charyzmatyczny czy też ewangeliczny rys nowej wspólnoty, który podlega dalszej ewolucji.

\section{EPOKOWA ZMiana W ROZUMIENIU KONSTYTUCjI}

Warto zatrzymać się nad wskazaną przed chwilą doniosłą rolą konstytucji dla życia duchowego osób konsekrowanych. Nierzadko, jak już zaznaczyłem na początku, są one rozumiane w sposób zredukowany, jako kodeks norm praktycznych, które regulują dyscyplinę instytutu. W konsekwencji można spotkać się z opiniami, że za mało jest w nich konkretnych przepisów. Części konstytucji poświęcone ideałowi życia przyjmowane są nieraz z pewnym zakłopotaniem, jakby nie tam było ich miejsce. Wydaje się, że wszystko to jest wyrazem przywiązania do wizji konstytucji, jaka obowiązywała przed Soborem Watykańskim II. Wówczas, na mocy instrukcji Kongregacji ds. Zakonów z 1921 roku, bazującej na Kodeksie prawa kanonicznego z 1917 roku, zakres konstytucji został ograniczony do kwestii stricte normatywnych i praktycznych. Zapisy o charakterze doktrynalnym i duchowym miały znaleźć się w innych kodeksach uzupełniających ${ }^{8}$.

Sobór Watykański II zmienił ten stan rzeczy (por. ESt II, 12-13, a także KPK 587 wraz z KPK 578). Postanowił on, że konstytucje mają przede wszystkim za zadanie określić w sposób autorytatywny tożsamość, powołanie i misję danego instytutu, nadto właściwy mu projekt życia ewangelicznego, $\mathrm{z}$ widocznymi cechami wyłaniającymi się z charyzmatu własnego. W ten sposób konstytucje stają się normą życia, nie zaś zbiorem norm praktycznych, czasem bardzo drobiazgowych. Ważna w nich będzie synteza elementów doktrynalnych, duchowych i jurydycznych. Wiele norm będzie miało fundamentalne znaczenie

5 Por. R. ZubieTa, El derecho de los Carmelitas Descalzos. Comentario doctrinal y juridico a las Constituciones de la Orden de Carmelitas Descalzos (1986), Burgos 2008, s. 8-9.

6 Por. M. Díez Presa, Las Constituciones. Lectura teológica y oracional, Madrid 1998², s. 53.

7 Por. E. Gambari, J. Lozano, G. Rocca, Fondatore. Personalità, w: Dizionario degli Istituti di Perfezione, red. G. Pelliccia, G. Rocca, t. IV, Roma 1977, kol. 96-97.98; J.M. Lozano, Fundador, w: Diccionario teológico de la vida consagrada, red. A. Aparicio Rodríguez, J. Canals Casas, Madrid 1989, s. 757. 761-762; F. CiARDI, In ascolto dello Spirito. Ermeneutica del carisma dei fondatori, Roma 1996, s. 53-54.

8 Por. R. Zubieta, Las Carmelitas Descalzas. Comentario doctrinal y jurídico a las Constituciones de las Monjas Carmelitas Descalzas (1991), Burgos 2006², s. 16. 
dla określenia życia i ewangelicznego zaangażowania członków instytutu. Jednocześnie odnowione konstytucje nie będą miały za zadanie podać wszelkich możliwych przepisów przydatnych w codziennym życiu, a tylko normy bardziej stałe. Inne, podlegające ze swej natury częstszym zmianom i adaptacjom zgodnie z czasem i miejscem życia poszczególnych wspólnot, winny się znaleźć w kodeksach uzupełniających (por. ESt II, 14). Pozwala to na realizowanie przez członków danej rodziny życia konsekrowanego wspólnego ideału życia i misji w różnorodnych formach.

Na poziomie doktrynalnym i duchowym konstytucje mają przekazać patrymonium instytutu: podstawy ewangeliczne i teologiczne życia konsekrowanego, jego związek z Kościołem, ideał przekazany przez założyciela i „zdrowe tradycje", czyli te elementy, które zostały włączone do istotnej spuścizny instytutu już po jego powstaniu'; w aspekcie jurydycznym mają zawierać podstawowe normy istotne dla określenia charakteru, celów i środków niezbędnych do realizacji nakreślonego ideału życia. Ta organiczna jedność między elementami doktrynalnymi i duchowymi $z$ jednej strony oraz jurydycznymi $z$ drugiej powoduje, że konstytucje nie mają charakteru czysto prawniczego albo jedynie egzortatywnego (por. ESt II, 12-13).

Wszystko to sprawia, że konstytucje w dzisiejszym ujęciu nie są rozumiane jako kodeks drobiazgowych norm, lecz raczej kodeks życia duchowego, swoista „księga życia”. Ma ona przede wszystkim opisać istotne postawy członków instytutu, jego wspólnot i instytutu jako całości. Konstytucje są więc prawem, ale przede wszystkim prawem życia, prawem przeznaczonym do bycia wyrytym „na żywych tablicach serc" (2 Kor 3, 3). I to przybliża je do źródeł Ewangelii. Właśnie z tych źródeł ostatecznie czerpią, określając sposób życia chrześcijan skupionych w konkretnym instytucie życia konsekrowanego ${ }^{10}$.

\section{Teologiczna lektura Konstytucji}

Skoro tak ma się rzecz z konstytucjami, można dokonać ich lektury teologicznej. Lektura taka pozwala z jednej strony zobaczyć je w pełniejszym świetle, $z$ drugiej może także posłużyć jako kryterium oceny, na ile konstytucje zostały opracowane rzeczywiście zgodnie z założeniami Soboru Watykańskiego II.

Klaretyn Macario Diez Presa już dość dawno temu opublikował książkę poświęconą lekturze teologicznej i modlitewnej konstytucji. Jest ona warta nie tylko

9 Por. W. Necel, Żyć charyzmatem chrystusowca, „Przegląd Polsko-Polonijny” 1(2012), s. 55, przyp. 3.

10 Por. R. Zubieta, Las Carmelitas Descalzas, s. 16-20. 
odnotowania, ale także przybliżenia polskiemu czytelnikowi ${ }^{11}$. Dlatego, idąc zasadniczo tropem tego autora, postaramy się wniknąć w znaczenie teologiczne konstytucji, pomijając to, co się odnosi do ich lektury modlitewnej. Zaproponowana lektura teologiczna obejmuje wymiary: patrylogiczny (określany w cytowanej książce jako teologiczny $)^{12}$, chrystologiczny, pneumatologiczny, mariologiczny, eklezjologiczny, antropologiczny, a także oferuje spojrzenie na posługę władzy, o której mowa w konstytucjach, z teologicznego punktu widzenia.

\subsection{Lektura trynitarna}

\subsubsection{Lektura patrylogiczna}

Odczytanie konstytucji w kluczu patrylogicznym polega na wejrzeniu w obraz Boga, jaki prezentuje ich tekst. Aby to uczynić, należałoby zadać sobie najpierw pytanie, do której Osoby Boskiej odnosi się słowo „Bóg” użyte w cytatach biblijnych obecnych w konstytucjach. Ponieważ, jak zauważa Karl Rahner, język biblijny odnosi wszystkie fragmenty mówiące o Bogu do Boga Ojca ${ }^{13}$, nie można inaczej rozumieć cytatów biblijnych zawartych w konstytucjach. Analogicznie jest z tekstami Soboru Watykańskiego II, który opisując wymiar trynitarny rzeczywistości, rezerwuje słowo „Bóg” dla Boga Ojca. Dotyczy to także ogółu piśmiennictwa teologicznego, jak mamy tego przykład w cytowanej książce.

Nie jest odkryciem stwierdzenie, że tekst konstytucji na różne sposoby będzie przekazywał obraz Boga Ojca jako miłości. Stanowi to element przewodni lektury konstytucji, a także klucz do interpretacji tego, co dotyczy rozważanego przez nas stanu życia. Św. Jan Paweł II powie: „Oto sens powołania do życia konsekrowanego: jest ono wyłączną inicjatywą Boga (por. J 15, 16)” (VC 17) ${ }^{14}$. Bóg, a mówiąc ściślej: Bóg Ojciec, wybiera i konsekruje. Konstytucje będą się starały nawiązać do tej miłości Boga, która objawia się w wybraniu każdego powołanego, i wskazać sposób odpowiedzi na nią. Docelowo będzie chodziło o to, aby rozbudzić w każdej osobie konsekrowanej głęboką świadomość życia dla s a m e go Bog a w różnych wymiarach powołania, takich jak kierowanie się na

11 Choć pozycja ta została już przywołana w całości w niniejszym artykule, wypada uczynić to w tym miejscu raz jeszcze: M. Díez Presa, Las Constituciones. Lectura teológica y oracional, Madrid $1998^{2}$

12 W odróżnieniu od Macaria Díez Presy proponuję użycie bardziej specyficznej terminologii, zaczerpniętejod jezuity Jeana Galota i na polskim gruncie upowszechnionejprzez Jana Daniela Szczurka (zob. jego rozprawa habilitacyjna: Bóg Ojciec w źródtach teologii. Zarys patrylogii, Kraków 2000). Innym rozwiązaniem jest zastosowanie terminu „paterologia”.

13 Por. K. RAhner, Escritos de teologia, t. I, Madrid 1961, s. 93nn.

14 Tekst łaciński mówi wprost o Bogu Ojcu: „Hic vocationis ad vitam consecratam significatio tota consistit: totum Patris ipsius inceptum est (cf. Io 15, 16)" (cyt. za: Enchiridion della Vita Consacrata. Dalle Decretali al rinnovamento post-conciliare (385-2000), wydanie dwujęzyczne, red. E. Lora, Bologna-Milano 2001, s. 3198). 
co dzień radami ewangelicznymi, życie w komunii we wspólnocie, pełnienie misji itd. Chodzi o wejście na płaszczyznę teologalną życia.

Rzeczywiście, osoba konsekrowana jest powołana przede wszystkim do życia ku chwale Boga. Nie jest to jednak aspekt oderwany, lecz ściśle związany z innymi, jak własne uświęcenie i troska o zbawienie innych. Streszcza on je i nadaje im właściwe znaczenie. Nie ma bowiem prawdziwego uświęcenia osobistego ani autentycznego apostolatu, które nie osiagnęły pełnej miary w oddawaniu chwały Bogu, w myśl teologii ojców Kościoła, według której wszystko zmierza ku Ojcu przez Syna w Duchu Świętym ${ }^{15}$.

Współczesne konstytucje instytutów życia konsekrowanego, które z natury rzeczy mają być przede wszystkim kodeksem życia duchowego, a więc życia w Duchu przez Syna dla Ojca, stanowią wyraz tego, jak być uwielbieniem Boga, jak żyć dla Boga. Można w tym miejscu powiedzieć, że osoba konsekrowana ukształtowana przez ich tekst staje się miejscem teologicznym, z którego rozpromienia się na świat chwała Boga. Jest to możliwe na tyle, na ile pozwala ona, aby Bóg objawiał w niej swoją świętość, miłość, opatrzność, bliskość, wsparcie ojcowskie i macierzyńskie. Oddawać chwałę Bogu oznacza być świadkiem tych rzeczy w sobie.

Warto dodać, że dla lektury patrylogicznej konstytucji duże znaczenie mają te ich fragmenty, które zawierają wyrażenie „wola Boża” albo mu podobne. O woli Bożej traktują zresztą także w sposób szczególny rozdziały mówiące o posłuszeństwie i o posłudze władzy, a w końcu cały tekst konstytucji. Są one bowiem, w ostatecznym rozrachunku, wyrazem woli Boga wobec instytutu życia konsekrowanego i jego członków, w każdym z istotnych aspektów życia. Należy jednak unikać pułapki traktowania woli Bożej w sposób wyłącznie jurydyczno-moralny. Wolę Boga wypełnia ten, kto potrafi kroczyć w miłości, w przekonaniu, że właściwie opracowane konstytucje są ku temu stosowną pomocą.

Przechodząc na tle powyższego do bardziej praktycznych wskazówek dotyczacych odczytania konstytucji w kluczu patrylogicznym, można wskazać na niektóre aspekty tejże lektury, formułując pytania: Jak konstytucje przekazują prawdę, że to Bóg konsekruje, i jak rysuje się w nich odpowiedź, jaką winni dawać powołani, osobiście i wspólnotowo? Na ile jest w nich wyrażony sposób, w jaki dany instytut życia konsekrowanego winien przeżywać wymiar patrylogiczny konsekracji i misji instytutowej? Czy istnieje w tekście komplementarność i harmonia między konsekracją a misją na rzecz królestwa Bożego? Czy zapisy konstytucji pobudzają wystarczająco do życia teologalnego? ${ }^{16}$

15 Por. IsaAC de Stella, De anima (PL CXCIV, 1888).

16 Por. M. Díez Presa, Las Constituciones, s. 33-49. 


\subsubsection{Lektura chrystologiczna}

Można powiedzieć, że lektura chrystologiczna konstytucji znajduje się $w$ centrum odczytywania ich w kluczu teologicznym. Życie konsekrowane jest bowiem wezwane do naśladowania Chrystusa w Jego ziemskim stylu życia; co więcej, poszczególne instytuty otrzymują jakiś szczególny aspekt Jego niezgłębionego Człowieczeństwa, jakąś tajemnicę Jego misterium, aby poprzez tę cząstkę być niejako sakramentalnym znakiem Jezusa Chrystusa, który nie przestaje żyć w swoim Kościele (por. LG 44, 46; PC 1).

Chrystusem modlącym się będą zainteresowane szczególnie konstytucje instytutów poświęconych życiu kontemplacyjnemu; nauczającemu Mistrzowi z Nazaretu uwagę poświęcą konsty tucje instytutów obdarzonych charyzmatem edukacji i wychowania; analogicznie będzie $z$ wyakcentowaniem Pana, który uzdrawia, kiedy weźmiemy do ręlki kodeks fundamentalny wspólnot powołanych do posługi chorym. Przykłady moglibyśmy mnożyć. Byłoby jednak błędem poprzestać na cząstkowym obrazie Chrystusa, ograniczonym do Jego wybranych słów, gestów, postaw. Konstytucje mają ostatecznie zaproponować powołanym integralny obraz Chrystusa. Jest on do odkrycia w poszczególnych Jego słowach, gestach, postawach. Osoby konsekrowane nie kroczą za Chrystusem pofragmentowanym, podzielonym, ale za Panem w Jego osobowej jedności, zachowując akcent właściwy charyzmatowi instytutu.

I tak tekst konstytucji zawsze ukaże Jezusa Chrystusa jako posłanego przez Ojca, jako syna człowieczego zanurzonego w życie ziemskie, jako mistrza, jako najwyższy wzór; ukaże Go w końcu w wydarzeniu paschalnym, choć uczyni to w kontekście misterium Chrystusa zajmującego szczególne miejsce w charyzmacie danego instytutu.

Tekst konstytucji proponuje więc obraz Chrystusa całościowy i zarazem specyficzny.

Osoby konsekrowane są zaproszone do naśladowania Pana, to znaczy do stopniowego upodobniania się do Niego. Ten proces chrystyfikacji wymaga zaangażowania i ciągłości, i mierzy w kształtowanie tożsamości osoby konsekrowanej. Nie polega on na odwzorowaniu postaw Chrystusa w znaczeniu czysto materialnym, lecz na teologalnym kroczeniu za Nim, co pozwala na kreatywne naśladowanie Go w kontekście czasu i miejsca, w którym przychodzi żyć osobie konsekrowanej.

Mówiąc o naśladowaniu Chrystusa w życiu konsekrowanym, nie sposób nie nawiązać do $\mathrm{rad}$ e wange liczny ch czystości, ubóstwa i posłuszeństwa. To one streszczają ziemski styl Jego życia oraz stanowią specyficzny przedmiot zainteresowania i wyróżnik wszystkich osób konsekrowanych w Kościele. Konstytucje poświęcają życiu według trzech rad zgodnie z charyzmatem własnym instytutu wiele uwagi. Ich lektura teologiczna w tym względzie będzie skupiona 
na tym, co stanowi o naśladowaniu Chrystusa czystego, ubogiego i posłusznego. Nie może zadowolić się wymiarem ascetycznym, moralnym czy prawnym.

I tak, lektura chrystologiczna w tym względzie zwróci uwagę, że ewangeliczna czystość daje osobie konsekrowanej, choć w sposób ograniczony, możliwość życia miłością ku Ojcu i ku ludziom, jaka wypełnia serce Jezusa, Odkupiciela świata. Objawi się to w oblubieńczej relacji do Boga oraz w serdeczności, czułości, współczuciu, delikatności, wrażliwości na drugiego człowieka, zwłaszcza na najsłabszych i ubogich. Ubóstwo pozwoli przeżywać siebie jako całkowity dar dla Boga i dla drugich, w wolności wewnętrznej. Po sł u s ze ens two będzie przeżywane jako całkowita otwartość i dyspozycyjność wobec zamysłu Bożego, który objawia się poprzez okoliczności życiowe, konkretne sytuacje i pośrednictwo ludzkie, zwłaszcza posługę przełożonych, prowadząc do chętnego angażowania się w sprawy królestwa Bożego.

Jak widać, wszystko to przewyższa wizję, która w życiu według rad ewangelicznych czystości, ubóstwa i posłuszeństwa widzi przede wszystkim wyrzeczenie się małżeństwa i założenia rodziny, ascetyczne odniesienie do rzeczy materialnych, podporządkowanie się przełożonym w relacji nierówności.

Mając na uwadze powyższe tło i przystępując w konkrecie do odczytania konstytucji w kluczu chrystologicznym, należałoby zwrócić uwagę na następujące sprawy: Jakie ewangeliczne fragmenty, jakie aspekty i przejawy Osoby Chrystusa stanowiły inspirację dla założyciela instytutu życia konsekrowanego? Jakie rysy, gesty, postawy Jezusa wobec Ojca i wobec ludzi dają się zauważyć w tekście konstytucji, obecne w nim na mocy charyzmatu własnego instytutu jako zaproszenie do naśladowania ich przez jego członków? Jaki aspekt tajemnicy Osoby Jezusa, nie gubiąc całościowego spojrzenia na Nią, jest typowy dla tożsamości członków instytutu? Które fragmenty ewangeliczne albo jakie przesłanie Jezusa szczególnie ich pobudzają? Na ile rozdziały poświęcone radom ewangelicznym zawierają jasne odniesienie do Osoby Jezusa i do upodobniania się do Niego? Czy ujęcia teologiczne przeważają nad wezwaniami do wyrzeczenia i ascezy? Jak jest umotywowane to, co odnosi się do wyrzeczenia i ascezy, czy to w zakresie ślubów, czy życia konsekrowanego w ogólności; czy jest wystarczająco zakorzenione w teologii? ${ }^{17}$

\subsubsection{Lektura pneumatologiczna}

Jako że konstytucje instytutów życia konsekrowanego są kodeksem duchowym każdego $z$ nich, $z$ natury rzeczy mają związek z Duchem Świętym. To On czyni możliwym życie w Bogu, życie chrześcijańskie w różnorodności jego form. Decyzja o obraniu konkretnego powołania i postępowanie na jego drodze nie są

17 Por. tamże, s. 51-71. 
tylko rezultatem wolnego wyboru osoby, ale przede wszystkim natchnienia, jakie daje Duch Święty (por. VC 19).

Obecność Trzeciej Osoby Boskiej w kodeksie fundamentalnym instytutów życia konsekrowanego jest bardziej dyskretna niż obecność Boga Ojca i Syna Bożego. Duch Święty przenika cały tekst konstytucji i ożywia go. Nie trzeba w tym miejscu wykazywać, że każdy charyzmat jest Jego darem. Warto natomiast przypomnieć, że tym, co jest najbardziej istotne i co najbardziej ożywia charyzmat założyciela, jest doświadczenie Ducha przekazane pierwszym członkom instytutu, aby nim żyli, strzegli go, pogłębiali i rozwijali; najpierw oni, potem ich następcy, wszystko w zgodzie z prawem ciągłego wzrostu mistycznego Ciała Chrystusa (por. MR 11; ET 11). Bez żywego doświadczenia Ducha można zachować osobowość jurydyczno-moralną w Kościele i w świecie, nie będzie się jednak osobami i wspólnotami charyzmatycznymi. Tylko „Duch daje życie" ( 6 6, 63).

W porównaniu z charyzmatem $\mathrm{duch} z$ a $\mathrm{to} \dot{z}$ yciel a jest bardziej subiektywny. Charyzmat odnosi się do powołania i misji, i do łaski Ducha Świętego potrzebnej do odpowiedzi ze strony człowieka. Natomiast duch założyciela wyraża już jego odpowiedź na otrzymany charyzmat. Ze względu na te różnice duch założyciela nie jest przekazywany jego duchowym potomkom w takiej samej mierze jak charyzmat. Nie pozostaje jednak dla nich bez znaczenia. Jest modelem, wzorem odpowiedzi na charyzmat otrzymany od Ducha Świętego, $z$ którym każdy powołany będzie musiał nieustannie się konfrontować w procesie dawania osobistej odpowiedzi Bogu.

Konstytucje pragną właśnie wyrazić, oprócz charyzmatu, ducha założycieli i związaną z nim duchowość instytutu. Jego członkowie będą w stanie odpowiedzieć na otrzymany charyzmat wówczas, kiedy, wzorem założyciela, pozwolą się prowadzić Duchowi Świętemu, nie rezygnując z życia według ducha i duchowości instytutu, tak jak są one przedstawione w konstytucjach. Chodzi tu nie tylko o rozdział poświęcony życiu duchowemu, ale o całość tekstu konstytucji, jako że różne jego części zawierają na swój sposób duchowość instytutu.

$\mathrm{Na}$ tle powyższego staje się zrozumiałe, że mimo iż Osoba Ducha Swiętego na ogół nie jest często przywoływana w tekście konstytucji, to właśnie On jest Tym, który inspiruje ich najgłębsze znaczenie. Można wyciągnąć wniosek, że kierowanie się konstytucjami jest gwarantem wierności Duchowi Świętemu. Konstytucje przekazują charakterystyczne elementy obiektywne danego instytutu. Każdy powołany ma za zadanie uczynić je swoimi w procesie subiektywizacji, to znaczy przeżywania elementów obiektywnych zgodnie z darami natury i łaski, jakie w sposób niepowtarzalny otrzymał od tego samego Ducha. 
Jeśli w życiu poszczególnych osób i wspólnot nie ma żywego doświadczenia Ducha, nie ma też życia duchowością, mimo wysiłków, by zachować ascetyczne i moralne wskazania konstytucji.

Ważnym aspektem odczytania pneumatologicznego konstytucji jest ich znaczenie dla wymiaru modlitewnego powołania. „Gdy (...) nie umiemy się modlić tak, jak trzeba, sam Duch przyczynia się za nami w błaganiach, których nie można wyrazić słowami” (Rz 8,26). Każda duchowość ma, by tak powiedzieć, klimat modlitewny, to znaczy atmosferę słuchania i odpowiadania Bogu, spotkania z Nim. Konstytucje mogą odegrać tutaj rolę przewodnika modlitwy. Nie tylko dlatego, że niektóre ich części, opisujące charyzmat i duchowość, nadają się do przemedytowania, ani że zawierają normy odnośnie do codziennej modlitwy, ale przede wszystkim dlatego, że stanowią „wymiar pustyni, skupienia i samotności"18 - Duch Święty mówi w nich i przez nie do serca człowieka, które potrafi dosłyszeć Jego głos. Stałe sięganie po konstytucje w tak rozumianym klimacie modlitewnym pozwala przyznać im rolę przewodnika, wychowawcy, kogoś, kto śpieszy z przestrogą czy też bije na alarm.

Mając to na uwadze, przy odczytaniu tekstu konstytucji w kluczu pneumatologicznym trzeba odpowiedzieć w pierwszym rzędzie na następujące pytania: Czy duchowość własna instytutu przedstawiona jest w nich jasno i w wystarczającym zakresie? Jak konstytucje wyrażają instytutowy charakter charyzmatyczny życia duchowego? Jakie oferują środki do życia duchowego? Jak ukazana jest w nich relacja między modlitwą osobistą i wspólnotową a misją instytutu? ${ }^{19}$

\subsection{Lektura mariologiczna}

Istnieje wiele instytutów życia konsekrowanego, które już w swojej nazwie mają odniesienie do Maryi. Jednak w niniejszym punkcie naszych rozważań nie chodzi o ten wymiar maryjności życia konsekrowanego. Nas interesuje fakt, że każdy rodzaj życia konsekrowanego, każda wspólnota są w istocie naznaczone rysem maryjnym, choć nie zawsze jest on otwarcie wyrażony w tekście konstytucji, a przynajmniej nie w całej rozciągłości. Życie konsekrowane jest na wskroś maryjne, ponieważ Maryja jest pierwszą uczennicą Syna Bożego (por. RM 20) i najlepszą przewodniczką na drogach naśladowania Go; jest pierwszą konsekrowaną Bogu i wzorem tej konsekracji (por. RM 39, 46).

Maryjna lektura konstytucji będzie w pierwszym rzędzie uważna na sformułowania wyrażające duchow ość ma ryjn ą zakorzenioną biblijnie, duchowość, która oznacza naśladowanie Chrystusa na wzór Maryi. Nierzadko tekst konstytucji wyrazi jakiś aspekt związku Maryi z Jej Synem, co rzuci światło

18 Tamże, s. 84.

19 Por. tamże, s. 73-88. 
na duchowość instytutu. I tak można spotkać określenia: Matka Chrystusa, Ta, która dała Go światu, Pierwsza uczennica Chrystusa, Służebnica Pańska itp. Może też być mowa o relacji Maryi do samych osób konsekrowanych: Matka, Królowa i Pani, Siostra, Mistrzyni życia duchowego, Wzór cnót ewangelicznych, Formatorka Apostołów, Inspiratorka nowych form życia konsekrowanego itd. Wszystko to stanowi zbiór tekstów zawierających doświadczenie maryjności w danym instytucie życia konsekrowanego. Owo doświadczenie może pobudzać do postępowania na drodze powołania z uwagą skierowaną na Maryję.

Oprócz tego lektura maryjna konstytucji zaczerpnie z głębokiego związku, jaki zachodzi między ewangeliczną istotą życia konsekrowanego a niektórymi istotnymi aspektami życia Maryi. Połączenie ich daje mocny wyraz temu, czym jest w najgłębszym wymiarze życie konsekrowane. Wspomniane aspekty życia Maryi nie zawsze są obecne explicite w tekście konstytucji. Jednak nie sposób odczytać do głębi istotę życia konsekrowanego bez postawienia w tle Maryi jako właściwej miary ewangelicznych wartości obranych przez osoby konsekrowane.

Poniżej zostaną wskazane rzeczone aspekty tajemnicy Maryi; bez szerszego komentarza, gdyż ich związek z ideałem życia konsekrowanego wydaje się wystarczająco jasny.

\subsubsection{Maryja, "petnia czasów”}

Bóg mógł wypełnić swoje obietnice, gdyż w Maryi napotkał w pełni to, czego oczekiwał od swojego stworzenia: duszę czystą i otwartą całkowicie na Niego w ubóstwie, pokorze, dyspozycyjności.

\subsubsection{Maryja, konsekrowana par excellence}

Po Jezusie Chrystusie Maryja jest najwyższym i najczystszym wyrazem osobistego oddania się Bogu i sprawie zbawienia (por. LG 56). Wszystko w Jej życiu odnosi się wprost do Boga, wszystko jest wyrazem Jej świadomej i wybranej więzi z Bogiem ${ }^{20}$.

\subsubsection{Maryja kontemplatywna}

Maryja zachowywała i rozważała w swym sercu słowo Boże (por. Łk 2, 19.51), odkrywając z czasem coraz głębsze jego znaczenie. Nie sposób zrozumieć nieraz krótkiej zachęty do medytowania słowa Bożego obecnej w tekście konstytucji bez odniesienia do kontemplatywnej postawy Maryi i stylu Jej życia

20 Można wskazać na wypowiedzi Magisterium Kościoła, które podk reślają szczególny związek osób konsekrowanych z konsekracją Maryi, np. LG 56, ET 56, RD 17, EE 53. 
w cichości, w nasłuchiwaniu, w refleksji mądrościowej. Milczenie jest środowiskiem dojrzewania do otwartości na Boga, a Maryja objawia jego głębię.

\subsubsection{Maryja, pierwszy świadek i pierwsza uczennica Chrystusa}

Zanim Chrystus skierował wezwanie „Pójdź za Mną” do Apostołów i innych osób, wezwał swoją Matkę do naśladowania Go i do świadczenia o Nim (por. RM 20). Maryja zawsze żyła w ścisłej więzi ze swoim Synem, więzi ożywianej nieustannie przez Ducha Świętego. Duch Święty zjednoczył Ją z Synem Bożym i z Jego misją już w momencie Zwiastowania. Świadectwo Maryi o Jezusie jest milczące i zarazem wielce przekonujące.

\subsubsection{Maryja dziewicza, uboga i postuszna stużebnica Pańska}

Najświętsza Maryja Panna jest uosobieniem ideału życia według rad ewangelicznych czystości, ubóstwa i posłuszeństwa (por. LG 56-57).

Dz i ewictwo jest niczym drugie imię Maryi. Wykracza dalece poza integralność cielesną i obejmuje wymiar charyzmatyczno-duchowy Jej osoby. Łączy się z pokorą, ubóstwem, ogołoceniem, całkowitą zależnością od Boga, uwidaczniającymi się zwłaszcza w dziewiczym macierzyństwie, pozbawionym udziału człowieka. Dziewictwo Maryi świadczy wymownie o mocy Boga, pozostawiając z boku możliwości ludzkie.

Ubóstwo Maryi wybija się na tle ubóstwa innych ludzi pokornych. Jest ono najpierw społeczne. Maryja, żyjąca w ubogiej części Galilei, zostaje poślubiona ubogiemu cieśli. Rodzi Jezusa w żłobie, gdyż nie było Ją wraz z Józefem stać na nocleg w gospodzie. Te i inne epizody z życia Maryi (por. Mt 2, 13; Łk 2 , $24 ; € k 23,23$ ) potwierdzają Jej przynależność do ubogiej klasy społecznej. Niemniej jednak sercem ubóstwa Dziewicy z Nazaretu jest ubóstwo w kategoriach królestwa niebieskiego. Jest Ona prawdziwą „ubogą Pana”, wzorem wyrzeczenia w służbie solidarności z innymi (por. Łk 1, 39-56; J 2, 3; Dz 1, 14).

Posłuszeńs two cechujące Maryję nie ogranicza się do zachowywania zasad życia religijnego (por. Łk 2, 22-24.27.39). Jest ono raczej wyrazem całościowej postawy Maryi wobec Boga (por. Łk 1, 38; LG 56, 61, 63), co umożliwia Mu zdziałanie w Niej i poprzez Nią rzeczy niesłychanych dla zbawienia świata. Przede wszystkim trzeba zauważyć, że tajemnica Wcielenia Syna Bożego zależała od posłuszeństwa Maryi: „Oto ja służebnica Pańska, niech mi się stanie według słowa twego" (Łk 1, 38; zob. także LG 56; RM 39).

W takich to aspektach możemy spojrzeć na Maryję, by zagłębić się w znaczenie wartości ewangelicznych istotnych dla tożsamości życia konsekrowanego. Choć, powtórzmy, konstytucje nie zawsze będą o nich mówiły w powiązaniu 
z Maryją, odniesienie ich do Matki Jezusa nadaje tym wartościom właściwą miarę i objawia głębię życia nimi.

Osoby konsekrowane są wezwane do tego, by u podobnić się do Maryi, aby w ten sposób pełniej oddać się Panu. Nie chodzi tylko o przybliżenie się do Niej od zewnątrz jako do wzoru postępowania, ale o komunię z Nią. Wzorczość Maryi jest owocem Jej czynnej obecności w Kościele w ogólności i w życiu konsekrowanym w szczególności (por. EE 53). Św. Jan Paweł II widzi w instytutach zakonnych promień czynnej obecności Maryi w Kościele (por. RM 28). W konsekwencji możemy powiedzieć, że nie tylko Jezus, ale i Maryja żyje w konsekrowanych. Konsekrowani Ją unaoczniają.

W ten sposób Maryja, choć nie jest w centrum uwagi konstytucji, jest jednak ich centralną postacią - ponieważ osoby konsekrowane nie mogą być takimi, to znaczy całkowicie oddanymi Panu, bez bycia na wskroś maryjnymi. W tym też kontekście należy rozumieć wezwania konstytucji instytutów życia konsekrowanego do codziennych aktów pobożności maryjnej. Winny one przyczyniać się do głębszego umiłowania Maryi, do naśladowania Jej i do pełniejszego przyjęcia Jej do własnego życia i apostolatu.

Na tle powyższego możemy wskazać kilka pytań pomocnych do odczytania konstytucji w kluczu maryjnym: Czy wyrażają one wystarczająco rolę Maryi w życiu i misji instytutu? Czy pobudzają do adekwatnej formacji początkowej i stałej w zakresie maryjności? Czy wymiar maryjny konstytucji wpływa na kształt wspólnoty: jej życie, modlitwę, apostolat, czy też raczej ogranicza się do indywidualnego życia poszczególnych osób? W końcu: czy akty pobożnościowe zalecane przez konstytucje i praktykowane we wspólnocie są przeniknięte tematyką biblijną i umacniają ducha do zaangażowania w głoszenie Chrystusa? ${ }^{21}$

\subsection{Lektura eklezjologiczna}

Przystępując do lektury eklezjologicznej konstytucji, należy zauważyć, że wykracza ona poza polecane w tekście posłuszeństwo papieżowi i pasterzom Kościoła oraz umieszczenie misji życia konsekrowanego w całości duszpasterstwa Kościoła lokalnego czy powszechnego.

W istocie chodzi o coś znacznie więcej, mianowicie o zwrócenie uwagi na fakt, że życie konsekrowane ży je tajemnicą Kościoła, będąc całew nim i dla niego, a także, że jest niczym ikona, obraz, znak Kościoła jako narzędzia zbawienia, który to Kościół ma swoje korzenie w tajemnicy Trójcy Świętej (por. LG 2-5).

Wiemy, że życie Kościoła toczy się wokół osi, którymi są koinonia, martyria, diakonia i liturgia. Jeśli więc życie konsekrowane ma być na wskroś eklezjalne,

21 Por. M. Díez Presa, Las Constituciones, s. 89-110. 
musi przede wszystkim dać się odczytać przez pryzmat tego, co oznaczają te pojęcia. Natomiast konstytucje instytutów życia konsekrowanego winny mówić o tych rzeczywistościach. Zobaczmy to z bliska.

Ko in onia (komunia, wspólnota) wskazuje na współdzielenie $z$ innymi tego, co najważniejsze, życia i samych siebie wraz z tym, co się posiada. Konstytucje w istocie odnoszą się do niej, kiedy mówią o życiu wspólnotowym, relacjach braterskich, posłudze władzy jako służbie na rzecz komunii i jedności. Wspólnota zakonna wciela i realizuje koinonię pierwszej wspólnoty chrześcijańskiej w Jerozolimie. Jest więc doświadczeniem dogłębnie eklezjalnym.

Martyria (świadectwo) jest żywą troską o to, by ludzie doszli do poznania Boga i przylgnęli do Niego. Konstytucje będą do niej sięgały, kiedy będą traktowały o charyzmacie instytutu, a więc o owym darze Ducha Świętego, który instytut otrzymał, a Kościół potwierdził. Służy on nie tyle dobru duchowemu członków instytutu, ile dobru Kościoła i świata. Chodzi tu o moc prorocką w głoszeniu Dobrej Nowiny całym swoim życiem.

Diakonia (służba) dotyczy bycia posłanym na rzecz innych. Wiąże się z martyrią, choć akcentuje bardziej aktywne zaangażowanie apostolskie niż świadectwo życia. Konstytucje, określając specyficzną misję instytutu i sposoby jej realizowania, wyrażają w rzeczywistości ten aspekt bycia przez konsekrowanych Kościołem, posłanym do pracy nad zbawieniem innych.

W końcu lit u rg i a, kult i uwielbienie Boga oraz celebracja tajemnic chrześcijańskich, przywoływana jest w konstytucjach, kiedy mówią o duchowości własnej instytutu jako specyficznym odcieniu duchowości Kościoła, a także o znaczeniu, formach i praktyce modlitwy, sakramentów, Eucharystii czy liturgii godzin. Przyznać trzeba, że liturgia zajmuje uprzywilejowane miejsce w stwarzaniu sensu eklezjalnego w życiu duchowym osób konsekrowanych.

Choć powyższe refleksje otwierają szeroki horyzont rozważań, przytaczany tu autor, Macario Díez Presa, wyodrębnia wymiar eklezjalny bezpośrednio w praktyce rad ewangelicznych $i-$ rzecz jasna - w ich prezentowaniu w konstytucjach.

I tak, cz y s to ść, która wiąże się z nowymi horyzontami kochania, jest tutaj widziana jako predysponująca do koinonii, a także znak diakonii.

Rada ewangeliczna ubóst wa wpisuje się w znaczenie martyrii, dając świadectwo całkowitej zależności od Pana i od Jego królestwa, jest także formą diakonii w służbie ubogacenia ich Bogiem i wartościami królestwa Bożego.

Natomiast posłuszeńs two, oznaczające przylgnięcie woli człowieka do woli Boga, jest swoistym znakiem sakramentalnym posłuszeństwa Jezusa względem Ojca. Jako takie stanowi oddawanie Bogu nieustannego kultu, uwielbianie Go życiem w nieustającej liturgii. 
Dodajmy, że aspekt liturgiczny da się również zauważyé w pozostałych dwóch radach ewangelicznych czystości i ubóstwa jako wyrazach konsekracji, całkowitego oddania się Bogu.

Jak dotąd, przyjrzeliśmy się osiom życia Kościoła, by w ich świetle odczytać ideał życia konsekrowanego opisany w konstytucjach. Oprócz tego, dla bardziej wnikliwej lektury eklezjologicznej konstytucji, możemy wziąć za punkt odniesienia cztery zn a mi o n a Kości o ła. Mówią nam one, że Kościól jest je de n, święty, powszechny i a postolski. Jak ma się to do tekstu konstytucji?

Jedność Kościoła oznacza jedność i komunię wierzących. Życie konsekrowane ze swoim życiem braterskim, a zwłaszcza życie zakonne, którego znakiem rozpoznawczym jest między innymi życie braterskie we wspólnocie, jawi się jako konkretny wyraz jedności Kościoła. Zgodne życie w jednej wspólnocie, dzielenie dachu i często pracy przez osoby, które nie wybierały siebie wzajemnie ze względu na atuty charakterologiczne, psychologiczne czy inne czynniki naturalne, jest wymownym znakiem, że „jeden Pan, jedna wiara, jeden chrzest” (Ef 4, 5) ma moc jednoczenia ludzi, którzy otwierają się na Boże wezwanie. Koinonia wspólnoty zakonnej jest w ten sposób znakiem komunii definiującej Kościół jako Ciało Chrystusa i jako lud Boży. Adhortacja apostolska Vita consecrata podkreśla ten aspekt, nazywając życie konsekrowane signum fraternitatis, „znakiem braterstwa”, „znakiem komunii w Kościele” (zob. rozdział II). Wszystko to, co konstytucje mówią na temat życia braterskiego, ma jasne odniesienie do Kościoła, który jest jeden.

Kościół święty. Wystarczy przypomnieć krótko, że życie konsekrowane nie należy do struktury hierarchicznej Kościoła, ale „do jego życia i świętości” (por. LG 44). Sobór Watykański II wskazuje w tych słowach na znamię świętości Kościoła jako definiujące życie konsekrowane. Nie sposób nie zobaczyć konkretyzacji tych treści zwłaszcza w konsekracji Bogu na drodze rad ewangelicznych, co jest nieodzownym tematem obecnym w każdym tekście konstytucji. Właśnie życie konsekracją sprawia, że osoby konsekrowane pobudzają do świętości lud Boży (por. LG 13, 39).

Trzecie znamię Kościoła, k a to li ck o ść, powszechność, łączy się z działaniem Ducha Świętego, który nieustannie aktualizuje i odnawia wydarzenie Pięćdziesiątnicy. Życie konsekrowane zaświadcza o tym dynamizmie działania Ducha poprzez bogactwo swoich form i bogactwo instytutów w całej historii Kościoła i na wszystkich szerokościach geograficznych. Nie należy też zapominać, że powszechnie obecne życie konsekrowane wezwane jest w sposób szczególny do ewangelizowania w każdym momencie historyczno-kulturalnym; co więcej, każda zmiana epokowa wiązała się przez wieki ze wzbudzeniem przez Ducha Świętego nowej formy życia konsekrowanego, zwłaszcza zakonnego, jako odpowiedzi na nowe wyzwania ewangelizacyjne. Możemy zauważyć w powszechno- 
ści misji życia konsekrowanego, którego wyrazem na gruncie kanonicznym jest egzempcja (por. KPK 586), eklezjalne znamię katolickości, powszechności samego życia konsekrowanego.

I w końcu, Kościół a postolski. Chodzi o wierność Kościoła misji, jaką Chrystus powierzył Apostołom. Znowu, specyficzna misja ewangelizacyjna życia konsekrowanego (por. AG 18,27), w wielości jego form, wyraża apostolskość Kościoła. Ponadto wyraża się ona także w nawiązaniu do stylu życia Apostołów wokół Pana, tworzących z Nim jedną wspólnotę dla misji. „I ustanowił Dwunastu, aby Mu towarzyszyli, by mógł wysyłać ich na głoszenie nauki" (Mk $3,14)$. Charyzmat i zaangażowanie w misję dają życiu konsekrowanemu udział w apostolskości Kościoła. Konstytucje zaś traktują o tych kwestiach niezbędnie.

Choć niemało już zostało powiedziane na temat lektury eklezjologicznej konstytucji, niech dopełnieniem tych treści będzie zwrócenie uwagi na fakt, że tekst konstytucji często ma na poziomie redakcyjnym różne wy rażenia, które zawierają ładunek eklezjologiczny. Na ogół w lekturze przechodzi się ponad nimi, nie wnikając w głębię ich treści. Warto więc dokonać małej egzegezy eklezjologicznej tych sformułowań.

- „Według naszego charyzmatu w Ko ści ele”. „Misja, jaką mamy w Kości el e”. „Pragniemy być w Kościele”.

Wyrażenia tego typu mówią o czymś więcej niż fizyczna przestrzeń obecności i posługiwania życia konsekrowanego. Mówią, że tak jak konsekrowani są w Chrystusie, tak też są w Kościele, są zanurzeni w misterium życia i misji Kościoła.

- „Instytut zatwierdzony przez Kościół”. „Instytut erygowany przez Kościół”. „Charyzmat rozeznany przez Kościół”.

Instytut wraz ze swoim charyzmatem nie pochodzi od Kościoła, jego dawcą jest Duch Święty. Kościół jednak, rozpoznając ten dar, traktuje go jako udzielony w pierwszym rzędzie sobie. Dar ten wpisuje się bowiem w porządek „życia i świętości" Kościoła (por. LG 44).

- „Jednamy się z Kościołe m” w sakramencie pokuty. „Niech kierują się duchem Kościoła”. „Kapituła Generalna szczepi doktrynę Kościoła o życiu konsekrowanym”. „Kościół zachęca nas”.

Tego typu sformułowania podkreślają głęboką komunię życia konsekrowanego z Kościołem, będącą znakiem autentycznej duchowości i zaangażowania apostolskiego.

- „Instytut na obraz Kościoła”. „Wspólnota charyzmatyczna i instytucjonalna na podobieństwo samego Kościoła".

Chodzi nie o zestawienie ze sobą dwóch oddzielnych rzeczywistości, zewnętrznych w stosunku do siebie, lecz o wewnętrzną przystawalność instytutu 
życia konsekrowanego do misterium Kościoła. Instytut uosabia Kościół, zwłaszcza w pewnych aspektach, poczynając od położenia akcentu na prymat Boga.

- „W służbie Kościoła”. „Dla dobra Kościoła”.

Wyrażenia tego typu podkreślają tożsamość apostolskości instytutu i apostolskości Kościoła. Innymi słowy, instytut życia konsekrowanego wpisuje się w Kościół apostolski.

- „Każdego dnia podejmujemy modlitwę w i m i e n i u Kościoła”.

Sformułowanie to i jemu podobne oddają wymiar kontemplacyjny Kościoła i życia konsekrowanego obecnego w konkretnym instytucie, podkreślając, że życie konsekrowane w sposób szczególny ucieleśnia Kościół modlący się.

Te wielorakie obserwacje pozwalają na stwierdzenie, że konstytucje instytutów życia konsekrowanego są w istocie prawdziwym przewodnikiem w przeżywaniu tajemnicy Kościoła przez osoby konsekrowane. Można na koniec sformułować trzy pytania-kryteria dla ocenienia eklezjalności tekstu konstytucji: Czy konstytucje wystarczająco i w sposób jasny lokują istnienie instytutu w rzeczywistości Kościoła? Czy życie instytutu opisane w konstytucjach, zwłaszcza życie wspólnotowe: życie modlitwy, życie braterskie i na poziomie apostolatu, jawi się jako przejrzysty znak tajemnicy Kościoła (w kontekście opisanych powyżej jego czterech osi i czterech znamion)? Jaki głęboki ładunek niosą konkretne sformułowania eklezjologiczne zawarte w konstytucjach? Choć są to zaledwie trzy pytania, domagają się wiele uwagi dla uzyskania dogłębnych odpowiedzi $i^{22}$.

\subsection{Lektura antropologiczna}

Odczytać konstytucje w kluczu antropologicznym oznacza wydobyć z nich treści traktujące o wartościach ludzkich, a także dostrzec rolę konstytucji w kształtowaniu w osobach konsekrowanych tego, co głęboko ludzkie.

Macario Díez Presa zwraca uwagę, że odnowa konstytucji po Soborze Watykańskim II miała na uwadze między innymi trzy przesłanki o charakterze antropologicznym. Były to kryteria: teologiczno-antropologiczne (jako remedium na ówczesny przesadnie jurydyczny i moralistyczny profil konstytucji), personalistyczne (w celu popierania pozytywnych i solidnych motywacji osoby w przeżywaniu własnego powołania, respektując wymogi wypływające z faktu bycia osobą ludzką) i socjo-historyczne (dla zapobieżenia alienacji osób konsekrowanych, uniemożliwiającej harmonijne życie i utrudniającej dotarcie do współczesnych z ewangelicznym przesłaniem). Takie usytuowanie życia konsekrowanego i konstytucji instytutów w kontekście antropologicznym

22 Por. tamże, s. 111-129. 
wzmacnia rolę humanizującą życia konsekrowanego i kodeksów fundamentalnych poszczególnych instytutów. W rzeczywistości, założenie antropologiczne przyjmuje, że konsekracja zakonna ma u podstaw niezbywalną bazę ludzką, bez której byłoby niemożliwe oddanie się Bogu. Nie można konsekrować się na wyłączną służbę Bogu inaczej, jak tylko z poziomu własnej tożsamości, wnosząc to, kim się jest, w nową perspektywę życia, a więc w dynamikę królestwa Bożego.

Zobaczmy pokrótce, jak konstytucje mogą i powinny czynić zadość potrzebie uwzględnienia wymiaru antropologicznego w prezentowaniu projektu życia osób konsekrowanych. Skupimy się najpierw na kwestii przeżywania siebie przez osoby konsekrowane, a następnie na przesłaniu, jakie winny one dawać światu poprzez swoje człowieczeństwo. Dla przejrzystości dyskursu Macario Díez Presa proponuje odniesienie do istotnych elementów życia konsekrowanego, jakimi są ślubowane rady ewangeliczne oraz, dodatkowo, życie wspólnotowe, gdy chodzi o życie zakonne.

\subsubsection{Konstytucje w służbie wartości ludzkich osoby konsekrowanej}

Konstytucje, opisując projekt życia osób konsekrowanych, powinny uwzględnić szereg danych o charakterze antropologicznym.

Jedną z elementarnych potrzeb człowieka jest potrzeba kochania i bycia kochanym. Stąd też antropologiczna wartość ewangelicznej rady czys tości tkwi nie w wyrzeczeniu się zawarcia małżeństwa i założenia rodziny, ale w życiu miłością w kontekście dokonanego wyboru celibatu dla królestwa niebieskiego. Celibat jest $z$ tego punktu widzenia specyficzną formą spotkania $z$ innymi, trwania $z$ nimi w wewnętrznych więziach czy we wspólnocie życia. Dzięki celibatowi miłość osoby konsekrowanej ma charakter powszechny, a ona sama staje się siostrą czy bratem wszystkich.

Dzięki zdolności do posiadania człowiek wchodzi w związek z rzeczami. Jednak sfera ta winna być regulowana nie przez „mieć”, ale przez „być” osoby ${ }^{23}$. Tylko wówczas posiadanie rzeczy humanizuje człowieka, czyni go bardziej ludzkim, co przejawia się w wewnętrznej wolności w stosunku do świata materialnego. Ubóstwo konsekrowane pozwala na uporządkowane odniesienie do rzeczy materialnych, chroni przed pułapką posiadania dla posiadania. Ponadto ubóstwo ewangeliczne broni transcendencji człowieka wobec rzeczy i świata oraz głosi, że rzeczy materialne, które człowiek posiada czy których używa, winny być zawsze w służbie wyższych wartości.

Idąc dalej, należy zauważyć, że wolność człowieka jest jednym z jego niezbywalnych praw. Autentyczne posłu szeńs two konsekrowane pomaga właściwie zagospodarować przestrzeń wolności. Ma uprzywilejowane miejsce w tym

23 Zob. G. Marcel, Być i mieć, Warszawa 1962; por. E. Fromm, Mieć czy być?, Poznań 1999. 
kontekście antropologicznym jako dobrowolna autodeterminacja na rzecz wartości wyższych. Takie posłuszeństwo nie wyklucza inicjatywności i odpowiedzialności (por. PC 14), które są cechami głęboko ludzkimi, co więcej, zakłada je, a posłuszeństwo bierne, jedynie wykonawcze, demaskuje jako wypaczone, gdyż nie odpowiada ono na wymogi antropologiczne.

Także ws pól nota zakonna nie może być wiarygodna bez respektowania wymiaru ludzkiego. Istotną jej cechą jest braterstwo, które oznacza wzajemne przyjmowanie się osób ludzkich tworzących wspólnotę. Zachowuje ono priorytet względem zewnętrznych zasad organizujących życie wspólne.

Uwzględniając te aspekty i nie ograniczając się do wizji jurydyczno-moralnej życia konsekrowanego, współczesne konstytucje powinny wspierać osobę w przeżywaniu siebie na drodze powołania $z$ uwzględnieniem wymogów antropologicznych.

\subsubsection{Konstytucje w stużbie humanizacji świata}

Projekt życia osób konsekrowanych zarysowany w tekście konstytucji instytutów stanowi sam z siebie przesłanie do świata, który, świadomy tego czy nie, potrzebuje wartości transcendentnych. Osoba konsekrowana, wcielając w życie ów projekt, staje się znakiem tych wartości; znakiem, który mówi, że wartości te mają moc ukształtować człowieczeństwo i odpowiedzieć na ważne egzystencjalne pytania. Będąc znakiem, projekt życia konsekrowanego wskazuje poniekąd kierunek tym, którzy pragną zagospodarować obszar ducha ludzkiego zgodnie z jego przeznaczeniem. Jednocześnie świadczy, że humanizm antropocentryczny, biorący za ostateczny punkt odniesienia człowieka, jest niewystarczający, a nawet szkodliwy. Dopiero humanizm teocentryczny, który afirmuje człowieka w świetle Objawienia, wyraża całą prawdę o nim.

W tym kontekście antropologicznym konsekrowana czys tość, daleka od ograniczenia do jałowego celibatu, wyraża się w komunii braterskiej, która realizuje się zarówno we wspólnocie zakonnej, jak i we wszelkich relacjach osoby konsekrowanej. Jest ona sposobem na kreatywne przeżywanie siebie jako istoty społecznej, z tym wszystkim, co oznacza życie dla innych. Takie zaangażowanie osób daje bodziec do budowania nowego modelu wspólnoty ludzkiej opartego na braterstwie.

Podobnie, a więc jako komunia uniwersalna, jawi się w rozważanym tu kontekście ewangeliczna rada u bós t wa, w tym, co odnosi się do dyspozycyjności i oddania siebie, swojego czasu, swych umiejętności i zaangażowania, a także dóbr materialnych na rzecz drugich, którzy są w potrzebie.

Nie inaczej należy widzieć posłuszeństwo osób konsekrowanych. Wobec rozpowszechnionego modelu zależności od władzy, w którym dobro osób podporządkowane jest różnorakim interesom, co nierzadko prowadzi do 
pomniejszania praw jednostki, a nawet do form zniewolenia człowieka, posłuszeństwo ewangeliczne wiąże się z poszanowaniem godności osoby ludzkiej, respektuje jej wolność, licząc na dojrzałe współuczestnictwo wszystkich w realizowaniu obranego ideału życia. Tym samym wspiera autentyczną wolność człowieka, wiążąc ją z prawdą i normą moralną (por. VC 91).

W zakresie ws póln oty życie konsekrowane ofiarowuje światu przykład solidarności, współdzielenia, wzajemnego poszanowania i jedności, wzajemnej akceptacji ludzi różnych kultur i ras (jak w przypadku wspólnot międzynarodowych), wolności od niezdrowego współzawodnictwa i zachowań agresywnych, gotowości do słuchania i dialogu. Niedoścignionym wzorem jest tutaj komunia Osób Trójcy Świętej. Ponadto, według Benedykta XVI, umiarkowany w zakresie materialnym styl życia wspólnot zakonnych jest prorocką odpowiedzią na sytuację zagrożenia katastrofą ekologiczną spowodowaną nadmierną eksploatacją środowiska przez człowieka ${ }^{24}$. W podobnym duchu wypowiada się również papież Franciszek (por. LS 214).

Podsumowując powyższe refleksje na temat lektury antropologicznej konstytucji, można stwierdzić, że projekt życia osób konsekrowanych jest rzeczywiście „duchową terapią” dla ludzkości, jak się wyraził św. Jan Paweł II, mówiąc na temat życia konsekrowanego jako opartego na radach ewangelicznych (por. VC 87).

Mając na uwadze to wszystko, możemy sformułować kilka pytań w celu ułatwienia lektury antropologicznej konstytucji: $\mathrm{Na}$ ile tekst konstytucji inspiruje przeżywanie głębokich wartości ludzkich? Jaki obraz człowieka wyłania się z ich treści? Czy konstytucje wyrażają w sposób jasny, że wyrzeczenia typowe dla projektu życia w nich opisanego służą kształtowaniu dojrzałego człowieka? ${ }^{25}$

\subsection{Konstytucje o zarządzie i animacji w życiu konsekrowanym w perspektywie teologicznej}

Na zakończenie części poświęconej lekturze teologicznej konstytucji chcemy na krótko poświęcić uwagę naturze posługi władzy w życiu konsekrowanym. Charakter charyzmatyczny i ewangeliczny życia konsekrowanego sprawia, iż każdy jego wymiar, także zarządzanie i animowanie, ma specyficzną, teologiczną konotację.

Przełożeni sprawują posługę władzy według konstytucji. One wyznaczają ramy ich działania na rzecz zarządzania i animowania życia powierzonych im osób i wspólnot. Jednak rola konstytucji nie ogranicza się tutaj do

24 Por. Benedykt XVI, Świattość świata. Papież, Kościót i znaki czasu, Kraków 2011, s. 56-58.

25 Por. M. Díez Presa, Las Constituciones, s. 131-156. Zob. także VC 87-91 oraz G. FirszT, Życie wedtug rad ewangelicznych, Kraków 2011, s. 79-88.92-102. 
zewnętrznego regulowania określonych sytuacji. Konstytucje, jak mogliśmy to zobaczyć dotychezas, przedstawiają konkretny całościowy projekt życia i jako takie służą wzbudzaniu tego życia, to jest realizacji zarysowanego projektu w konkretnych osobach. Stąd też animacja życia w oparciu o konstytucje jest sprawą teologiczną i charyzmatyczną. Domagać się będzie ze strony przełożonych postawy ewangelicznej służby na rzecz wzrostu królestwa Bożego, poczynając od wspierania osób tworzących wspólnotę. Od pozostałych konsekrowanych wymagać będzie szczerego realizowania sposobu życia zadeklarowanego w profesji zakonnej.

Macario Díez Presa stwierdza, że sprawowanie posługi władzy według konstytucji oznacza położenie akcentu zwłaszcza na trzy kwestie. Są to:

Odniesienie do Ewangelii, jako że konstytucje w swej istocie są niczym komentarz do Ewangelii napisany przez dany instytut życia konsekrowanego, poczynając od doświadczenia charyzmatycznego założyciela, o czym była mowa w niniejszym artykule.

Relektura Ewangelii w kluczu danego instytutu, gdyż chodzi o zarządzanie i animowanie właśnie w oparciu o konstytucje. Warto w tym punkcie zauważyć, że nie każdy zapis konstytucji ma dla tej relektury taką samą wartość. Na pierwszym miejscu będą tutaj rozdziały początkowe, które podają ideał charyzmatyczny jako normę życia.

Perspektywa ws pólnotowa, ze względu na fakt, że - jak zaznacza cytowany autor - w żadnym punkcie konstytucje nie są sprawą tylko indywidualną danej osoby. Są kodeksem duchowym całego instytutu, współdzielonym przez wielu powołanych. Towarzyszenie poszczególnym osobom, $z$ ich niepowtarzalnymi darami natury i łaski, winno dokonywać się w ramach wspólnego projektu życia.

W konsekwencji możemy powiedzieć, że konstytucje, wbrew temu, co może się wydawać na pierwszy rzut oka, wskazują na o wiele pełniejszy model władzy w życiu konsekrowanym niż ten, który ogranicza się do odpowiedzialności za decyzje o charakterze administracyjnym. Jest to model całościowy, w służbie nie tylko dobrego funkcjonowania organizacji, jaką jest instytut czy dana jego część, ale także i przede wszystkim w służbie życia, które toczy się w instytucie i we wspólnotach ${ }^{26}$.

26 Por. M. Díbz Presa, Las Constituciones, s. 157-169. 


\section{ZAKOŃCZENIE}

Konstytucje instytutów życia konsekrowanego przeszły po Soborze Watykańskim II istotną przemianę. Z tekstu dyscyplinarnego o charakterze jurydyczno-prawnym stały się kodeksem życia duchowego, który wzniosłe ideały przekuwa na normy służące zachowaniu tożsamości członków danego instytutu w Kościele. Odpowiada to ewangelicznym korzeniom samego życia konsekrowanego. Właśnie taki profil konstytucji stanowi o ich wysokiej wartości dla życia powołaniem konsekrowanym.

Jest oczywiste, że dla duchowego wzrostu na drodze powołania niezbędne jest sięganie do pism założyciela i innych ważnych postaci instytutu, napełnianie nimi umysłu, poszerzanie horyzontów mentalnych, zwłaszcza jeśli byli oni teologami wielkiego formatu. Dobrze opracowane konstytucje przedstawiają, w części traktującej o charyzmacie i duchowości, ideał życia przekazany przez założyciela w postaci normy życia. Ma to duże znaczenie dla przejścia od theoria do praxis. W ostatecznym rozrachunku chodzi przecież o ukształtowanie stylu życia, codziennych wyborów, wykształcenie specyficznego profilu osoby, jej tożsamości. Uważna i życzliwa lektura konstytucji w osnowie wielkich pism duchowych instytutu sprawia, że osoba konsekrowana otrzymuje pedagogiczną pomoc w stawaniu się tym, kim już jest. 


\title{
RIASSUNTO
}

\section{GrzegOrz FIRSZT OCD}

Le costituzioni degli istituti di vita consacrata come codice di vita spirituale

L'articolo presenta il valore che le Costituzioni degli istituti di vita consacrata hanno per la vita spirituale dei consacrati. E lo possono avere perché sono il codice fondamentale di una forma di vita che, in sostanza, è evangelica. Nel testo viene toccata la fisionomia delle Costituzioni prima e dopo il Concilio Vaticano II, e segnato l'influsso sui consacrati che conserva ancora il concetto preconciliare. Esso fa sì che le Costituzioni siano contemplate piuttosto come testo giuridico-morale e non un testo, in primo luogo, di portata carismatico-spirituale. Per approfondire la spiegazione delle Costituzioni come codice di vita spirituale, l'autore presenta una loro lettura teologica, basandosi sulla proposta del claretiano Macario Díez Presa. Si arriva alla conclusione che come la lettura degli scritti dei fondatori e di altri personaggi rilevanti dell'istituto è indispensabile per la crescita spirituale dei consacrati, così non pochi articoli delle Costituzioni sono d'aiuto, sia sul piano pratico che su quello teorico, in ordine all'ideale di vita basato sul carisma e sugli elementi essenziali della vita consacrata.

\begin{abstract}
GrzegOrZ FirszT OCD

The Constitutions of Institutes of Consecrated Life as a Blueprint for Spiritual Life

The article sets out the value which the constitutions of institutes of consecrated life have for the spiritual life of the consecrated persons. Constitutions can have this value because they are the legal expression of a fundamentally evangelical form of life. The article describes constitutions as they were before the Council and their expression after the Council, paying attention too to the ongoing influence of the preconciliar model on consecrated persons now. This influence can mean that constitutions are read as juridical and moral texts rather than as writings with charismatic and spiritual importance. In order to study more deeply their potential as a blueprint for spiritual life, the author offers a theological reading, in the light of suggestions by the Claretian Macario Díez Presa. The conclusion reached in this article is that, just as an indispensable tool
\end{abstract}


for the spiritual growth of consecrated persons is the reading of texts by their founders and by others who have been significant for the particular institute, so in a similar way many parts of the constitutions offer practical and theoretical help towards realizing the ideal of life based on the charism and on essential elements of consecrated life.

Słowa klucze: rady ewangeliczne, życie konsekrowane, konstytucje Keywords: evangelical counsels, consecrated life, constitutions 